\section{Response to: 'Pitfalls of antinuclear antibody detection in systemic lupus erythematosus: the positive experience of a national multi-center study' by Pregnalato et al}

We appreciate the comments by Pregnolato et $a l^{1}$ on our original paper ${ }^{2}$ and subsequent correspondence in the journal. ${ }^{34}$ The data presented are very interesting and suggest that, under certain circumstances, results of antinuclear antibody (ANA) testing with samples from patients with established systemic lupus erythematosus can show both a high frequency of positivity and high concordance among testing laboratories. Such agreement may result from the nature of the samples themselves, including the titre of the antibodies and the array of specificities present, the kits used for the assays and the experience and training of the observers. While we would acknowledge that ANA assays can perform very well, our experience as well as that in the literature indicates that variability occurs significantly in a way that complicates screening of patients for clinical trials. Notwithstanding the demonstrations of the kind reported by Pregnolato et al, we think that it is important to try to understand assay variability and improve serological determinations for both routine care as well as clinical research.

\section{David S Pisetsky, ${ }^{1}$ Diane M Spencer, ${ }^{1}$ Peter E Lipsky, ${ }^{2}$ Brad H Rovin ${ }^{3}$ \\ 'Department of Medicine and Immunology, Duke University Medical Center and Medical Research Service, Veterans Administration Medical Center, Durham, North Carolina, USA \\ ${ }^{2}$ RILITE Research Institute, Charlottesville, Virginia, USA \\ ${ }^{3}$ Division of Nephrology, Department of Internal Medicine, Ohio State University, Wexner Medical Center, Columbus, Ohio, USA}

Correspondence to Dr David S Pisetsky, Department of Medicine and Immunology, Duke University Medical Center, Durham, NC 27705, USA; david.pisetsky@duke.edu
Handling editor Josef S Smolen

Funding The authors have not declared a specific grant for this research from any funding agency in the public, commercial or not-for-profit sectors.

Competing interests None declared.

Patient consent Not required.

Provenance and peer review Commissioned; internally peer reviewed.

(c) Article author(s) (or their employer(s) unless otherwise stated in the text of the article) 2019. All rights reserved. No commercial use is permitted unless otherwise expressly granted.

\section{Check for updates}

To cite Pisetsky DS, Spencer DM, Lipsky PE, et al. Ann Rheum Dis 2019;78:e51.

Received 26 April 2018

Accepted 26 April 2018

Published Online First 5 May 2018

\section{Linked}

- http://dx.doi.org/10.1136/annrheumdis-2018-213516

Ann Rheum Dis 2019;78:e51. doi:10.1136/annrheumdis-2018-213582

\section{REFERENCES}

1 Pregnolato F, Borghi MO, Meroni PL. Forum Interdisciplinare per la Ricerca sulle Malattie Autoimmuni (FIRMA) Study Group. Pitfalls of antinuclear antibody detection in systemic lupus erythematosus: the positive experience of a national multicentre study. Ann Rheum Dis 2019;78:e50.

2 Pisetsky DS, Spencer DM, Lipsky PE, et al. Assay variation in the detection of antinuclear antibodies in the sera of patients with established SLE. Ann Rheum Dis 2018;77:911-3.

3 Mahler M. Lack of standardisation of ANA and implications for drug development and precision medicine. Ann Rheum Dis 2019;78:e33.

4 Pisetsky DS, Spencer DM, Lipsky PE, et al. Response to: 'Lack of standardization of ANA and implications for drug development and precision medicine' by Mahler. Ann Rheum Dis 2019;78:e34. 